\title{
SEASONAL VARIABILITY OF PHYTOPLANKTON BLOOMS IN THE COASTAL WATERS ALONG THE EAST COAST OF INDIA
}

\author{
T. Preethi Latha ${ }^{\mathrm{a}, *}$, K. H. Rao ${ }^{\text {a }}$, E. Amminedu ${ }^{\text {b }, ~ P . ~ V . ~ N a g a m a n i ~}{ }^{\text {a }}$, S. B. Choudhury ${ }^{\text {a }}$, E.Lakshmi ${ }^{\text {c }}$, \\ P. N. Sridhar ${ }^{\text {a }}$, C. B. S. Dutt ${ }^{a}$, V. K. Dhadwal ${ }^{\text {a }}$ \\ a National Remote Sensing Centre, Hyderabad \\ b Dept. of Geo-Engineering, Andhra University, Visakhapatnam \\ c National Institute of Technology, Warangal \\ * pritilata1309@gmail.com
}

Commission VI, WG VI/9

KEY WORDS: Phytoplankton Blooms, Variability, Coastal Waters, OCM-2

\begin{abstract}
:
Bay of Bengal (BOB) is a semi enclosed tropical basin located in the north eastern part of the Indian Ocean with high influence of fresh water discharge from major rivers and rainfall. Bay of Bengal (BOB) is highly influenced by monsoons and represents a natural laboratory to study the effect of fresh water fluxes on the marine ecosystem. Bay of Bengal (BOB) is very low in productivity often with the observations of Phytoplankton Blooms. Phytoplankton blooms are one of the prominent features of biological variability in the coastal ecosystems such as estuaries, lagoons, bays, and tidal rivers with rapid production and accumulation of phytoplankton biomass in the ocean. These blooms usually respond to changing physical forcings originating in the coastal ocean like tides, currents and river runoff and to the atmospheric forcing like wind. These physical forcings have different timescales of variability, so algal blooms can be short-term episodic events, recurrent seasonal phenomena, or rare events associated with exceptional climatic or hydrologic conditions. Bloom events and their variability on spatial \& temporal scales monitoring through field measurements is difficult. Based on this key hypothesis an effort is made to understand the seasonal and spatial variability of Phytoplankton Blooms along the East Coast of India. In this paper we present the bloom dynamics in their context to the chlorophyll concentration along with species composition and abundance in estuarine and near shore coastal waters of Godavari basin using Oceansat-2 Ocean Colour Monitor (OCM). The initial results revealed that the quasi permanent phytoplankton blooms initiates in the month of midFebruary and evolves for a period of two months and then slowly starts decaying by the mid of May month. The results also stand as a base for the study of influence of Phytoplankton Blooms on the carbon flux estimations and bio-geo-chemical processes in the Bay of Bengal.
\end{abstract}

\section{INTRODUCTION}

Applications of satellite remote sensing have given powerful insight to the study of marine and freshwater ecosystems, providing information spatially and temporally at a global scale. Since 1970s, scientists have used satellites to detect the optical signatures of constituents present in surface water (O'Reilly et al., 1998). Satellite measurements are especially useful for the detection of phytoplankton because of the unique spectral characteristics of photosynthetic pigments (Richardson, 1996). Blooms are classically defined as a "rapid increase of algae over time with abundant amount of one of the phytoplankton species" (Smayda, 1997). Bloom that indicates discoloration of coastal water is a matter of concern for the local communities and government agencies because of its harmful effect on human health (Choudhury et al., 1989). Phytoplankton blooms in surface waters of lakes, estuaries and coastlines result from the combination of natural and anthropogenic impacts. Nutrients, coastal upwelling and sufficient amount of sunlight produce some of the largest algal blooms in the world's oceans because nutrients play an essential role in supporting a phytoplankton bloom and Phytoplankton depends on the sunlight and available nutrients for their energy and growth. Terrestrial runoff from the industrial, agricultural, residential and urban areas may also raises the nutrient loads to the near shore and inland waters in the ocean. Phytoplankton blooms in the coastal waters or in the estuarine systems can vary in magnitude and duration as responses to variable factors like river inflow, vertical and horizontal stratification, turbulent mixing, nutrient and light availability. Bloom dynamics are complicated issues in the coastal ecosystems having large spatial gradients in these forcings, as well as in bathymetry. The growth environment of phytoplankton is either directly or indirectly set by the physical environment.

In the coastal waters along the east coast of India, an Asterionella Japonica bloom was reported around Waltair i.e., Visakhapatnam coast (Subba Rao, 1969), along the Orissa coast (Choudhury and Panigrahy, 1989; Panigrahy and Gouda, 1990; and Mishra and Panigrahy, 1995). It was proved from the above identifications of the blooms in the coastal waters that the dominance of Diatoms is more in the Bay of Bengal. According to research findings of Sarma et al. in 2009 \& 2010 on the Godavari basin, the Godavari estuary is net heterotrophic where water column respiration exceeds the mean photic zone productivity and also identified the river discharge as the major source of nutrients. From the analysis of Acharya et al, 2012, the inter-annual variability of phytoplankton in Godavari estuary found a mechanistic link between the phytoplankton bloom and monsoon driven river discharge. They also identified that the period during the months of October - November as the bloom period in the Godavari basin during the years 2007, 2008 and 2009 which resulted from reduced river discharge and observed high Chlorophyll- $a$ concentrations up to $14.1 \mathrm{mg} / \mathrm{m}^{3}$ with low suspended particulate matter. The lower turbidity and higher stability of the water column also facilitates the formation of phytoplankton blooms, which can also be governed by the amount of freshwater discharge into the estuary. 
Understanding the variability in bloom dynamics and the associated physical mechanisms is important in predicting how ocean biology will respond to climate change. The seasonal cycle of phytoplankton growth is a key driver of the biological carbon pump. Monitoring of bloom composition, frequency and intensity provides important indicators of degraded water quality (Richardson, 1996). Quantification of these bloom events requires both one is what a bloom constitutes and second is continuous time series measurements of phytoplankton. Bloom identification or monitoring criteria are subjective, varying among research efforts according to the regional dynamics, sampling frequency, and methods applied. Threshold criteria, for instance, define blooms as any value that deviates from a median or other static value in a time series (Henson and Thomas, 2007b; Siegel et al., 2002a; Wilson, 2003). The threshold approach is useful for the determination of bloom frequency and persistence in certain regions; but due to the regional and seasonal variability of the bloom events at short and long time scales may complicate the efforts to define a static threshold for blooms. However, a continuous source of data at daily to weekly time scales along with large spatial extent i.e., satellite data, is required.

Remote sensing data of surface chlorophyll also show the contrast of productive coastal water and oligotrophic offshore water in the oceans. Satellite ocean colour data provide synoptic, long term time series coverage for identification of these bloom events. At a large spatial extent and at global to regional scale the ocean colour datasets were useful in detection and monitoring of phytoplankton blooms. However, satellite ocean colour data from very near shore waters have systematic and random errors due to the optical complexity of near shore water caused by organic and inorganic suspended particles and bottom reflectance (Kim et al., 2009; Darecki and Stramski, 2004; Kahru and Mitchell, 1999).Two ocean colour data products currently available to the global community of Chlorophyll- $a$ concentration from Ocean Colour Monitor (OCM-2) onboard the Oceansat-2 mission and the Moderate resolution Imaging Spectroradiometer (MODIS) aboard the Aqua spacecraft are used as a tracer in identification of the blooms for the present study. The phytoplankton bloom observed during the months of February - May in the coastal waters of Bay of Bengal i.e., in the Godavari Basin (Kakinada and Yanam regions) was studied in the present paper for the first time. The OCM-2 derived Chlorophyll- $a$ data from the year 2012 to 2014 were analyzed to study the seasonal distribution of the bloom in space and time scale. The seasonal variability of the bloom event is also observed in comparison with the monthly climatology of the MODIS data which is available from 2002-2014 for the five months from January to May. The present study is mainly focused on the bloom that initiated in the winter season and persisted up to the summer season. The satellite observations of the phytoplankton bloom event in the Godavari basin has been validated with the in-situ measurements collected in the month of March 2012 during the blooming period for a period of ten days (i.e., from 02-10 March, 2012). The in-situ measurements includes the optical radiance measurements, water sample data extracted for Chlorophyll, TSM concentrations and the pigments data from HPLC analysis along with the cell count data from microscopic analysis.

\section{STUDY AREA}

Godavari is the largest of Indian peninsular rivers; the river divides into two main distributaries Gautami and Vasishta which gives rise to an estuarine deltaic system with tidal creeks and dense mangrove forests before reaching the Bay of Bengal. The Godavari estuary is well mixed up with the tidal effect dominating in the lean season (Preethi et al, 2013). The shallow Kakinada bay opens into the sea on its northern side and is bordered along by a narrow sand bar. The coastal morphology of this entire Godavari regime has been explained in detailed by K.N.Rao et al., 2003. The study region considered for the present study in identification of the bloom event from the ocean colour datasets comprises of the entire Godavari basin (Figure 1(a)) with in a $4 \times 4$ degree region covering from $15-19^{0} \mathrm{~N}$ latitudes and $81-85^{\circ} \mathrm{E}$ longitudes along the east coast of Bay of Bengal. From this grid area of the study region, the spatial extent and movement of the bloom can be defined clearly. Along with the study region considered for monitoring of blooms, the validity of the existence of the bloom event from the in-situ measurements collected in the study area during March 2012 also encompasses the coastal waters of the Godavari basin along Off Kakinada and Yanam during March $2-10,2012$ covering 21 stations from $16^{0} 41.125^{\prime} \mathrm{N}$ to $16^{0}$ 58.099' $\mathrm{N}$ latitudes and $82^{0} 32.141^{\prime} \mathrm{E}$ to $82^{0} 23.425^{\prime} \mathrm{E}$ longitudes as shown in Figure 1(b). Among all the 21 stations, 19 stations covers the Coastal waters (Case-2) at varying depths from surface to $75 \mathrm{~m}$ whereas 2 stations covers the intermediate waters (almost Offshore waters) varying from $100 \mathrm{~m}$ to $150 \mathrm{~m}$ of depth covering the Godavari estuarine region of the Bay of Bengal.

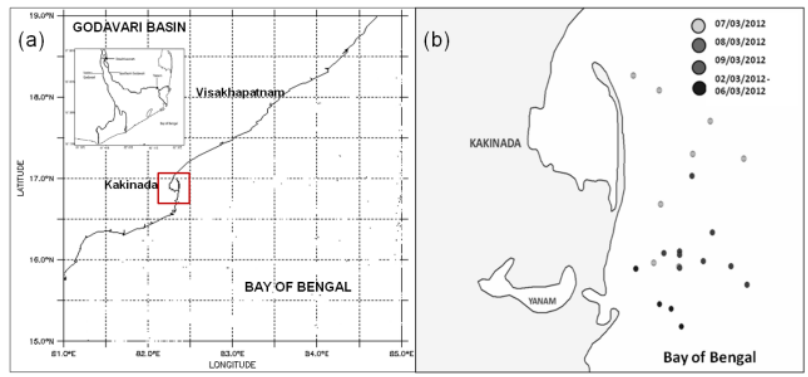

Figure 1. (a) Map showing the study area Godavari Basin and (b) Locations of in-situ sampling station in and around Kakinada and Yanam. (In set image shows the entire course of the river Godavari along the east coast of India.)

\section{DATA AND METHODS}

\subsection{Satellite Ocean Colour Datasets}

The OCM-2 Local Area Coverage (LAC) data with $360 \mathrm{~m}$ resolution for the study period i.e., from January to May for the years 2012, 2013 \& 2014 were used in the study. The OCM -2 data has 8 spectral bands in Visible and NIR regions with two day repetivity i.e., the satellite covers the entire North Indian Ocean in two days using four paths of $8,9,10,11$ in which 8 \& 9 covers the Arabian Sea and $10 \& 11$ covers the Bay of Bengal. The each path was sub-divided in to $3 / 4$ rows/scenes with a ground swath of $1420 \mathrm{~km}$ with 3730 x 6026 dimensions of each row. As the study area in this study was confined to the coastal waters of Bay of Bengal (Godavari Basin), only the $10^{\text {th }}$ pass covering the western Bay of Bengal was used. The processing of OCM2 imageries were implemented with SeaDAS version6.4 software (running on LINUX and IDL). As is well known, SeaDAS is globally accepted ocean colour data analysis software equipped with advanced processing features in which OCM-2 has been incorporated. The present processing sequence of OCM-2 in SeaDAS involves the conversion of level1b (L1B) data to level2 (L2) format and also from level2 (L2) to level3 (L3) format. The process of generating the L2 products involved with different processing methods along with atmospheric correction, flagging and masking with appropriate thresholds for cloud, land and glint affected areas / pixels, a correction of suitable algorithm will be applied to the raw 
radiances from the L1B datasets for the scene/area. The derived water leaving radiances data are then used as input for the different bio-optical algorithms for the retrieval of chlorophyll concentrations. In this regard, the existing chlorophyll algorithm like OC4-V4 (O' Reilly et al., 1998) was used for estimating the chlorophyll concentrations. The retrieved daily standard L2 chlorophyll data were spatially averaged to $\mathrm{L} 3$ of $1 \mathrm{Km}$ resolution using the spatial binning (L2bin) method and the daily binned products were temporally binned to 8-day (weekly) products using the time binning (L3bin) method of SeaDAS. This has been done to attain the good number of valid pixels over the spatial domain considered. The 10+ years (2002 onwards) of consistent Moderate Resolution Imaging Spectroradiometer (MODIS) ocean color data (oceancolor.gsfc.nasa.gov.in) provides an invaluable record of Climatological datasets. This study uses the Level 3 Monthly Climatological chlorophyll data i.e., from January to May of Aqua MODIS from 2002-2014. For the validation of the bloom event with the in-situ chlorophyll data, the simultaneous raw OCM-2 LAC L1B data with native resolution $360 \mathrm{~m}$ for the corresponding in-situ data period i.e., 02-09 March 2012 were also acquired and processed.

\subsection{In-situ Datasets}

3.2.1 Water Sample Collection for Pigment extraction and Species Cell count: The in-situ water sample data were collected at 21 stations in the cruise dates in coincidence with the OCM-2 satellite pass. Sampling was carried out daily by collecting seawater from 7 depths $(0,5,15,25,30,50$ and $75 \mathrm{~m})$ using Niskin water samplers. Filtrations were done immediately, using Whatman $\mathrm{GF} / \mathrm{F}$ filters and stored $-20^{\circ} \mathrm{C}$. To extract the phytoplankton pigments by HPLC analysis a GF/F filter (pore size $0.7 \mu \mathrm{M}$ ) was used and the frozen filters were immersed in $3 \mathrm{ml} \mathrm{95 \%} \mathrm{acetone} \mathrm{(v/v}$ in de ionized water) for extraction using a sonicator probe $(5 \mathrm{~s}$, $25 \mu \mathrm{M})$ under low light and temperature $\left(4^{\circ} \mathrm{C}\right)$ followed by storage at $-20^{\circ} \mathrm{C}$ for $4 \mathrm{~h}$. Pigments Analysis was done by High Performance Liquid Chromatography (or high pressure liquid chromatography) as per the JGOFS protocols 1994. For validation with the satellite chlorophyll measurements the extracted Chlorophyll- $a$ pigment concentration from HPLC were used in the study. Phytoplankton cell count was estimated using standard Sedgwick rafter cell and species identification were done using Desikachary et.al. (1987).

\section{RESULTS AND DISCUSSION}

\subsection{Identification of the Bloom from Satellite Observations}

The seasonal variability in the timing and magnitude of the phytoplankton bloom in the Godavari basin is examined using the satellite data of OCM-2 and Aqua MODIS. Though there is no method or threshold exists to define the phytoplankton blooms due to various phytoplankton communities, different quantitative definitions of phytoplankton blooms have been used in several studies by Henson and Thomas (2007) and Siegel et al. (2002) chose $5 \%$ above annual median values of surface chlorophyll to define initiation times of blooms. Kim et al. (2007) also considered the weekly averaged surface chlorophyll maximum concentrations during the spring and fall seasons as the blooms without defining any quantitative threshold. In this study, the bloom was defined based on 8-day (weekly) surface chlorophyll concentration for the study area to observe the percent relative change in the standard 8day chlorophyll products during the blooming seasons over time.

4.1.2 Seasonal Distribution of Chlorophyll-a: The weekly mean chlorophyll concentrations retrieved from the OCM-2 data were analyzed for the Godavari basin region for two seasons of winter and summer of 2012, 2013 and 2014. Analysis of the weekly chlorophyll products for the study region of Godavari basin for the years 2012, 2013 and 2014 indicate the inter and intra seasonal variation with relative changes in the mean chlorophyll concentrations (Figure 2). Visual interpretation of each year chlorophyll products from Figure 2, Figure 3 and Figure 4 suggests that two main types of bloom patterns occurred i.e., winter and summer blooms. In the year 2012, from Figure 2, a small bloom patch was observed in the first and second week of February around $16.30 \mathrm{~N}$ to $16.50 \mathrm{~N}$ region along the coast with a mean value of $1.01 \mathrm{mg} / \mathrm{m}^{3}$ which is shifting towards the north with decrease in the chlorophyll concentration of 0.9 $\mathrm{mg} / \mathrm{m}^{3}$ in the third and fourth weeks of February. And in the month of March the bloom has initiated again by moving towards the north with a mean value of $1.08 \mathrm{mg} / \mathrm{m}^{3}$ during all the four weeks. Whereas in the case of April month, though the bloom has been intensified with a large spatial extent up to $18^{0}$ $\mathrm{N} ; 84.5^{\circ} \mathrm{E}$ to the offshore waters but the mean chlorophyll is ranging between $0.9-1.07 \mathrm{mg} / \mathrm{m}^{3}$. But the $95 \%$ threshold pixel values are showing $\sim 2 \mathrm{mg} / \mathrm{m}^{3}$ of chlorophyll pixels which are confined to the bloom area. In the month of May the bloom has intensified more with a $95 \%$ threshold value of $2.24 \mathrm{mg} / \mathrm{m} 3$ with a mean chlorophyll of $1.12 \mathrm{mg} / \mathrm{m}^{3}$ and a secondary peak of bloom was also observed at $18^{0} \mathrm{~N} ; 84^{0} \mathrm{E}$ combining with the intensified bloom emerged from Godavari coast. This may also result in the high mean values of chlorophyll during the May month. In 2013, similar trend was observed as in 2012 with initiation of the bloom in February second week at $16.6^{\circ} \mathrm{N}$; $83.3^{0} \mathrm{E}$ with a mean value of $1.4 \mathrm{mg} / \mathrm{m}^{3}$ and was continued towards the north with decrease in the chlorophyll concentration of $1.04 \& 1.06 \mathrm{mg} / \mathrm{m}^{3}$ in the third and fourth weeks of February. It intensified in the March with a mean value of $1.12 \mathrm{mg} / \mathrm{m}^{3}$ during all the four weeks. During April the bloom intensified in the two weeks with $1.34 \mathrm{mg} / \mathrm{m}^{3}$ restricted to the northern part but in the third and fourth weeks the bloom has been shifted to the southern part with a decrease in the chlorophyll values of $1.14 \mathrm{mg} / \mathrm{m}^{3}$. And it was intensified more in May with increasing chlorophyll values ranging from 1.25 $1.9 \mathrm{mg} / \mathrm{m}^{3}$ shifting southward at the end of the month. In 2014 , the similar patterns of bloom were existed but the initiation was started in the first week of February with a mean value of 1.35 $\mathrm{mg} / \mathrm{m}^{3}$ in the entire month and with its intensification in March, April and May with high chlorophyll ranges of $1.2-1.8 \mathrm{mg} / \mathrm{m}^{3}$, $1.4-1.54 \mathrm{mg} / \mathrm{m}^{3}, 1.3-1.5 \mathrm{mg} / \mathrm{m}^{3}$ with more intensification as shown in figure 4 .

During all the three years, the similar trend was observed that the bloom initiation in the month of February and was restricted to the northwestern Bay of Bengal. In the months of March and April with its intensification and spatial extent from $16.7^{0} \mathrm{~N}$ to $17.3^{0} \mathrm{~N}$ to $18^{0} \mathrm{~N}-85^{\circ} \mathrm{E}$ is observed. The onset of blooming is observed every year during April. This also indicated changes in governing forces that trigger blooming in the area. During the blooming period, the study area experiences seasonal winds and the wind is in the northeast direction during winter and at the end of winter, in February, when the winds are still northeasterly, the current along the western boundary reverses and flows northward. The East India Coastal current (EICC) peaks during March- April, when the winds are weak (Shetye et al.,1993) and in May, prior to the intensification of summer monsoon, the EICC gets weaken and reverses to a southward flow in the northern part (Shetye et al., 1991). Along the East Coast of India, the water flow reverses its direction to north seasonally from January with the East Indian Coastal Current (EICC) and East Indian Winter Jet to south in the rest of the months (Choudhury et al., 1989). The cumulative effect of wind 


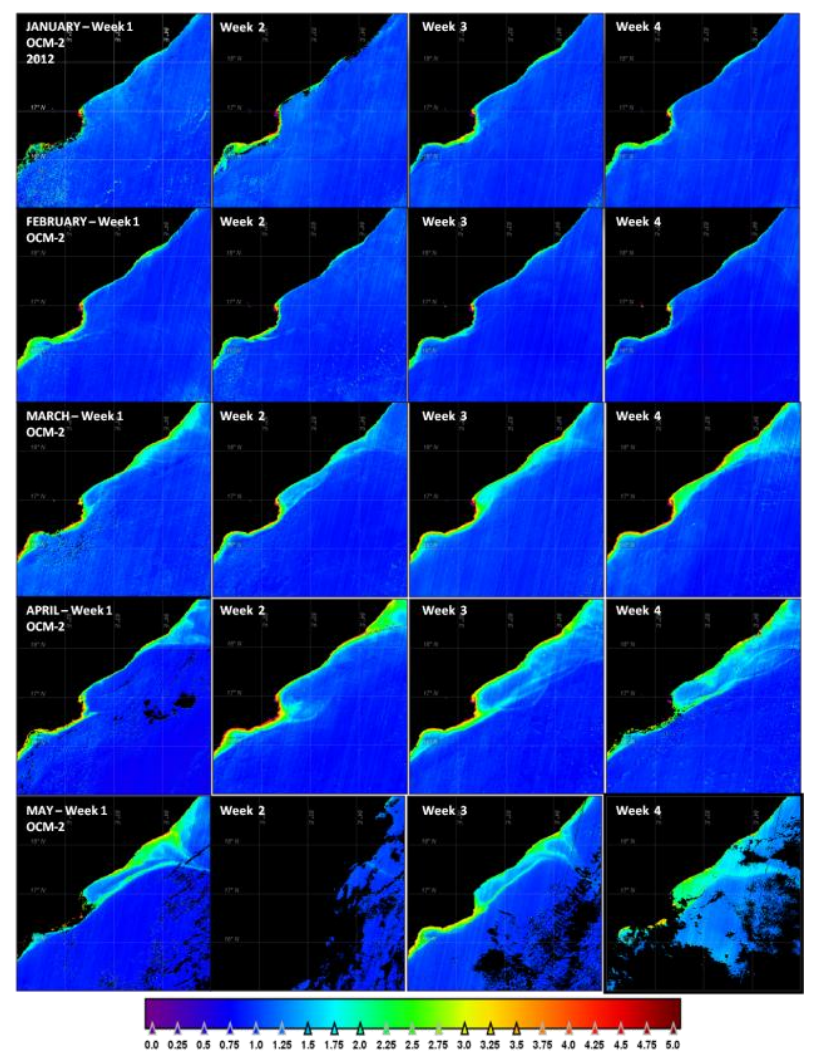

Figure 2. 8-day (weekly) Chlorophyll products of OCM-2 from January to May, 2012.

driven forcing leading to the coastal upwelling enhances the productivity in the region leading to the summer blooming situation along the Bay of Bengal coast. During the winter season, the winter mixing process brings up the nutrients from the deep waters on the surface layers and warmer temperatures during with increased sunlight allow the phytoplankton to absorb the energy for photosynthesis along with nutrients and the phytoplankton gets multiplied with sufficient amount of sunlight and nutrients thus favoring the bloom condition. This can be observed clearly from the chlorophyll data of OCM-2 during the summer season in 2012, 2013, and 2014 during the months of March, April and May with increasing mean chlorophyll concentration. In the summer season, observations of blooms could potentially arise after the winter mixing of the subsurface chlorophyll maximum into the surface water. The maximum subsurface chlorophyll concentration during summer can be higher than those in the surface water which is also observed from the Figure 5, showing the low surface chlorophyll values in the early two weeks ( 9 \& 10) of March during 2012, 2013 and the early two weeks ( $9 \& 10$ ) of March during 2012, 2013 and 2014.

Certain changes were observed during the years from 2012 to 2014 in terms of chlorophyll concentration that could be attributed to local physical forcing in the area. The seasonal variability observed in the spatial patterns, timing and magnitude of the seasonal phytoplankton bloom is partly due to underlying local physical forcing. Even though summer blooms can be short-lived, the limited observation made during March 2012 have captured the valuable information regarding the intensity and dominating phytoplankton species helps in hypothesizing the summer bloom dynamics in the Godavari Basin. Thus, the blooms also result from the active growth of phytoplankton population supported by the input of new nutrients to the surface water.

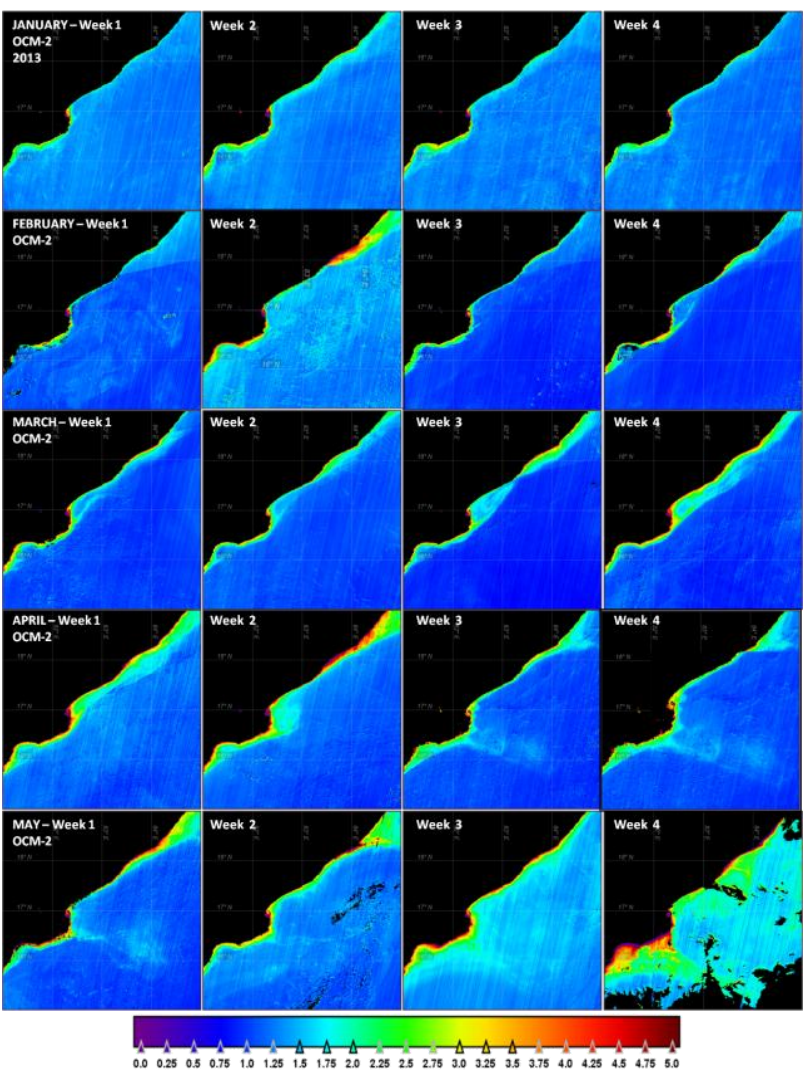

Figure 3. 8-day (weekly) chlorophyll products of OCM-2 from January to May, 2013

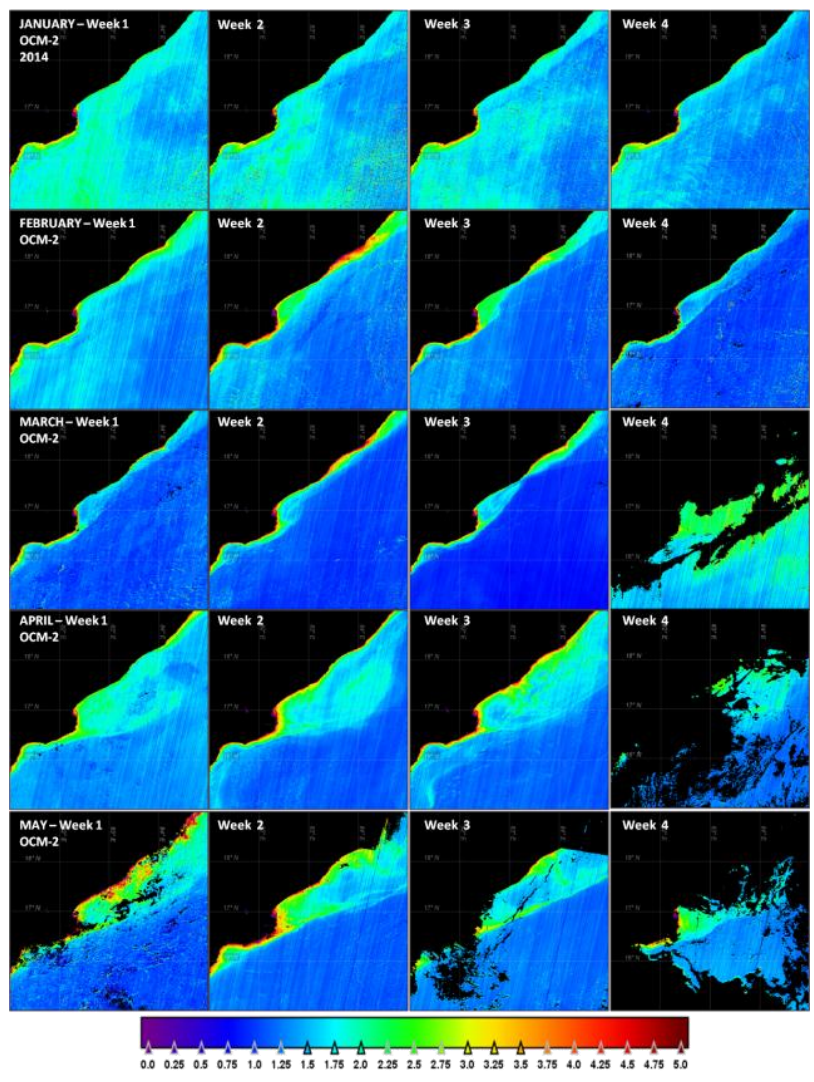

Figure 4. 8-day (weekly) chlorophyll products of OCM-2 from January to May, 2014. 


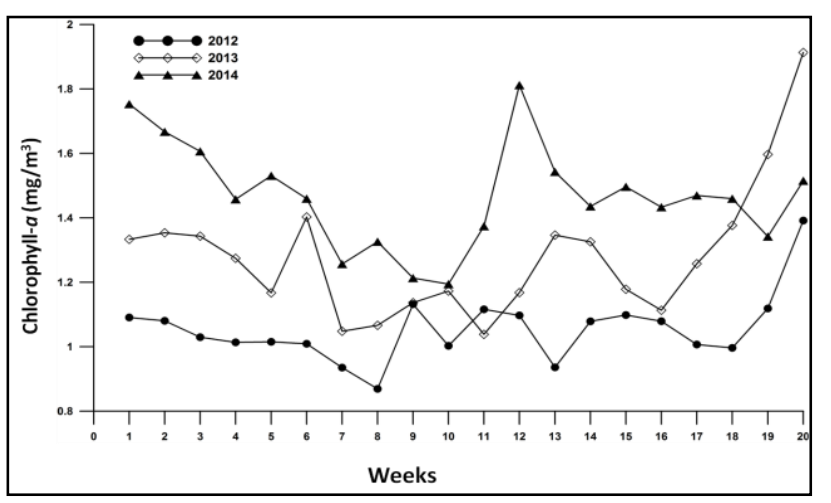

Figure 5. OCM-2 8-day (weekly) mean Chlorophyll- $a$ concentration from January to May for the years 2012, 2013 \& 2014.

4.1.3 Seasonal Variability observed from MODIS: In comparison with the seasonal variability of the bloom observed from OCM-2, the monthly climatology of the Chlorophyll data of MODIS from 2002 to 2014 also showing the similar trend as shown in the Figure 6. The monthly climatology of Chlorophyll in the Godavari basin is also showing the initiation of the bloom in February and intensified in April and persisted up to May indicating the summer bloom. Note that the maximum chlorophyll, corresponding to the climatological summer bloom, occurred in April, whereas its evolution was started in the month of February i.e., in the winter season with a small magnitude of chlorophyll. The structure of the seasonal cycle of the summer bloom observed in the each year of 2012, 2013 and 2014 from OCM-2 is also observed from the climatology chlorophyll data.

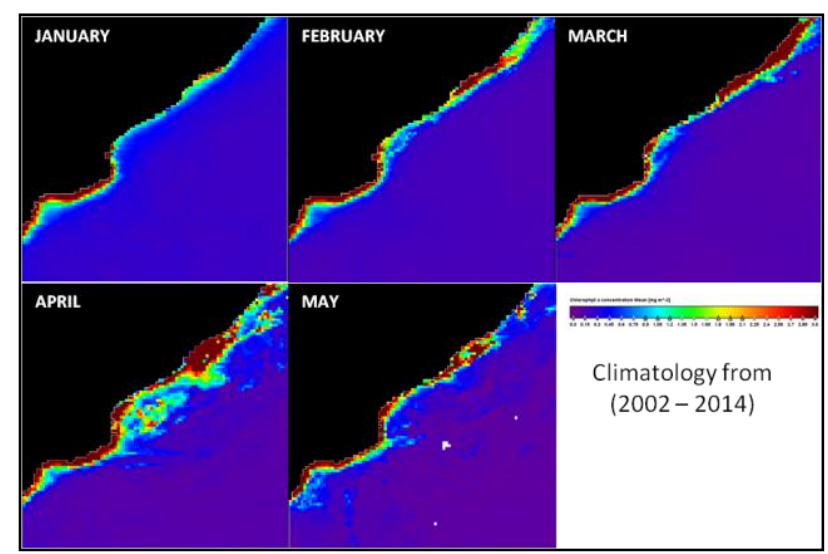

Figure 6. Monthly Climatology chlorophyll of A-MODIS from January to May.

\subsection{Validation of the identified bloom with In-situ Observations}

4.2.1 Satellite Chlorophyll Validation: The spatial distribution of Chlorophyll- $a$ concentration for the corresponding in-situ dates are shown in Figure 7. Validation of the chlorophyll concentrations was carried out by comparing Chlorophyll- $a$ derived from OCM-2 images (Figure 7) with in-situ data collected concurrently ( \pm 2 hours). A total of 33 matching Chlorophyll- $a$ measurements were considered for comparison of in-situ HPLC data and 10 matching data points were found for the corresponding OCM-2 passes on 03, 05, 07 \& 09 between 02 - 09 March 2012. Comparison of chlorophyll retrieved from Satellite with in-situ measured chlorophyll showed good correlation $\left(\mathrm{R}^{2}=0.6\right)$ (Preethi et al., 2013).

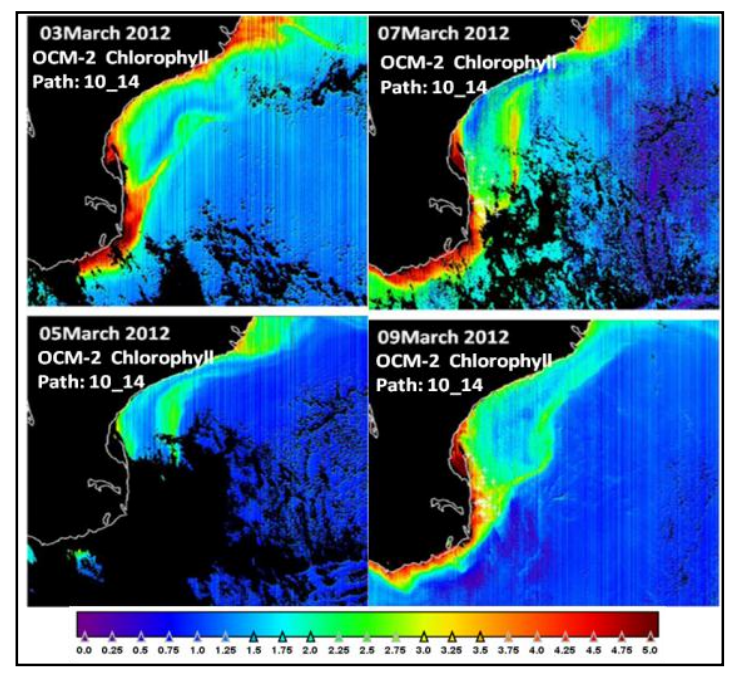

Figure 7. Spatial distribution of Chlorophyll- $a$ derived from OCM-2 on corresponding cruise dates in March 2012.

4.2.2 Phytoplankton abundance and taxonomy: The coastal phytoplankton bloom in Godavari estuary was observed in second week of February, 2012 and continued till early April 2012. The similar condition also prevails in 2013 and 2014 with a time lag of 2 weeks. The water sample data collected during 02-09 March in 2012 for phytoplankton abundance estimation on the surface waters of the Godavari basin and the locations are shown in the Figure 1(b). The significant species contributing to the occurrence of bloom given in Table 1 indicates the functional composition of the phytoplankton community which does not change during the blooming season, whereas a single species become more dominant with increasing biomass. During the blooming phase in March 2012, the cell counts increased by three orders. Thus, the species assemblage indicated the dominance of Cheatocerous sp. and Skeletonema Costatum in blooming phase. The dominance of diatoms observed with its share of more than $90 \%$ of total phytoplankton composition as shown in the Figure 8. The total phytoplankton community comprised of 139 species of which 66 belonged to Diatoms, 33 belongs to Pennales while 31 species were Dinoflagellates and about 9 species of Cyanobacteria were identified. In the blooming phase, during 03,05,07 and 09 March 2012 only 13 species were observed which high cell counts during its peak bloom situation in April 2012 as shown in Table-1. In the entire period of observation, only 7 species of diatoms such as, Chaetoceros curvisetus, Chetocerous sp., Lauderia annulata, Skeletonema costatum Bacillaria 


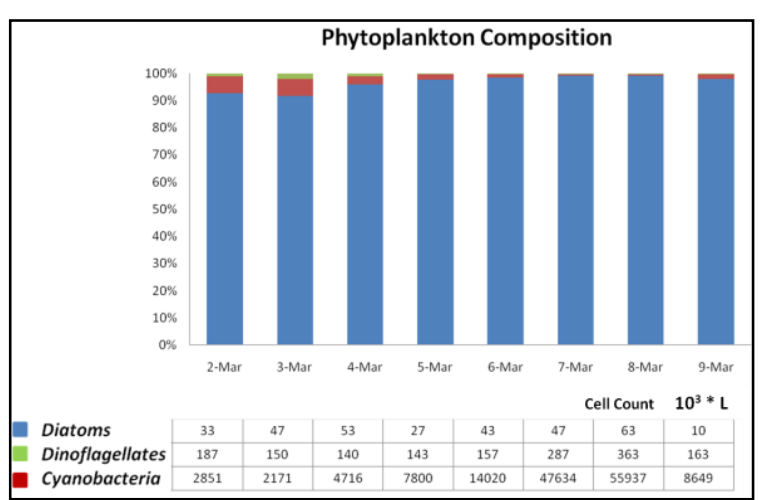

Figure 8. Total Phytoplankton composition, partitioned into three dominant groups and the total proportion(\%) of the dominating group

paxillifera, Thalassionema nitzschioides, Thalassiothrix frauenfeldii. But Skeletonema Costatum dominated the entire phase of blooming in the area with an abundance of 32,477 under the dominant group of diatoms. It is observed that the Godavari basin area is exhibited by diatom bloom during March 2012. High chlorophyll concentrations on the surface layer derived from OCM2 corresponding to the cruise dates with a maximum of $3.4 \mathrm{mg} / \mathrm{m}^{3}$ on 07 March 2012 and associated increase in cell count confirms the occurrence of Skeletonema Costatum bloom in the study area. The occurrence of this phytoplankton bloom in the study region is also studied for the years 2013 and 2014 from OCM-2 chlorophyll data.

Table 1. The number of observations of a species with the highest count contribution (dominating species) to an identified summer phytoplankton bloom.

\begin{tabular}{|c|c|c|c|c|c|}
\hline $\begin{array}{l}\text { Functional group \& } \\
\text { Species Identification }\end{array}$ & 03 March 2012 & 05 March 2012 & 07 March 2012 & 09 March 2012 & \\
\hline DцAтомs & Cell Count $10^{3} \cdot \mathrm{L}$ & Cell Count $10^{3} \cdot \mathrm{L}$ & Cell Count $10^{3 \cdot} \cdot \mathrm{L}$ & Cell Count $10^{3} \cdot \mathrm{L}$ & TOTAL count \\
\hline Chaetoceros curvisetus & 360 & 980 & 2393 & 1473 & 5206 \\
\hline Chaetocerossp. & ${ }_{93}$ & 2817 & 3543 & 980 & 7433 \\
\hline Gunardiaflaccida & ${ }_{17}$ & 33 & ${ }_{73}$ & , & 130 \\
\hline Guinardia striata & $\infty 0$ & 203 & ${ }_{457}$ & 167 & 887 \\
\hline Lauderia ammulata & ${ }_{147}$ & 130 & 2333 & 663 & 3273 \\
\hline Leptocylindrus minimus & ${ }_{93}$ & 460 & 313 & 53 & 919 \\
\hline Paralia sulcata & 300 & 0 & 23 & 30 & 353 \\
\hline Skeletonema costatum & ${ }_{37}$ & 0 & 30273 & 2167 & 32477 \\
\hline Bacillaria paxililifera & 1287 & 10 & 243 & 。 & 1540 \\
\hline Nitschia striata & 280 & ${ }_{93}$ & 27 & ${ }_{73}$ & 473 \\
\hline Pleurosigma normanii & 177 & 20 & ${ }_{43}$ & 13 & 253 \\
\hline Thalassionema mitschioides & 7 & 140 & 2253 & 90 & 3380 \\
\hline Thalassiothrix fracuenfeldit & ${ }_{40}$ & 403 & ${ }_{1337}$ & , & 1787 \\
\hline \multicolumn{6}{|l|}{ DINOFLAGELLATES } \\
\hline Ceratium furca & 57 & 27 & 33 & o & 117 \\
\hline Peridinium stetmi & ${ }_{30}$ & 37 & 97 & 0 & 164 \\
\hline \multicolumn{6}{|l|}{ CYANOBACTERLA } \\
\hline $\begin{array}{c}\text { Anabaenasp. } \\
\text { Trichodesmium Erythraea }\end{array}$ & $\begin{array}{c}27 \\
3\end{array}$ & $\begin{array}{l}20 \\
3\end{array}$ & $\begin{array}{l}23 \\
23\end{array}$ & 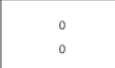 & $\begin{array}{l}70 \\
29\end{array}$ \\
\hline
\end{tabular}

4.2.3. HPLC Pigment analysis: Along with the phytoplankton composition data the HPLC measured ancillary pigments concentration were also analyzed. The Figure 9, shows a total of 9 pigments concentration collected from surface to subsurface depth up to $25 \mathrm{~m}$ on par with the satellite passes of OCM-2 showing a maximum concentration of Chlorophyll- $a$ pigment of $\sim 2.5 \mathrm{mg} / \mathrm{m}^{3}$ on surface and also even high values observed in the sub surface depths ranging from 1.6 to $0.7 \mathrm{mg} / \mathrm{m}^{3}$ on 07 March 2012. This high peak of chlorophyll is also represented in the Phytoplankton abundance data with a highest cell count species of Skeletonoma

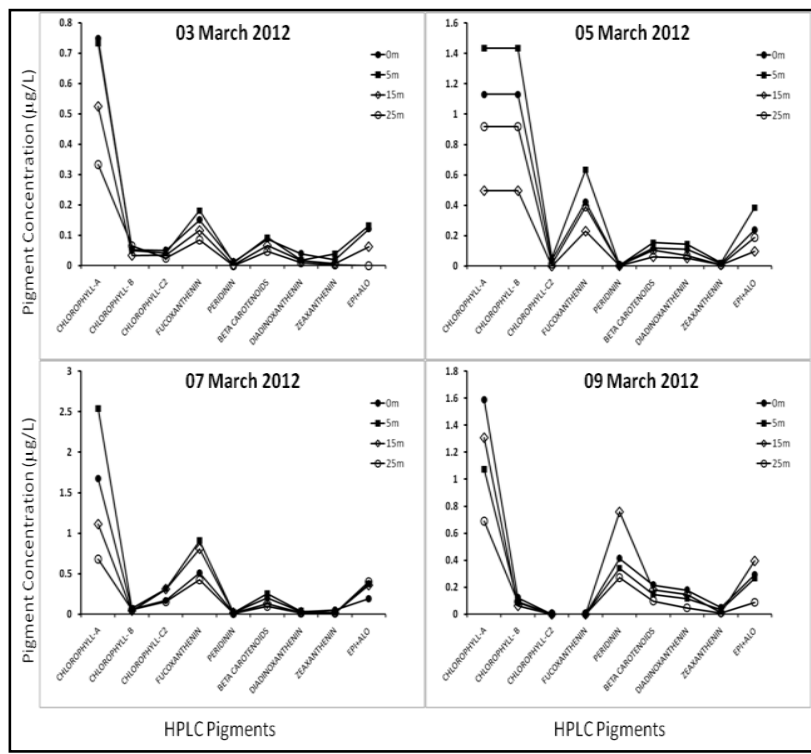

Costatum at that location during the blooming period. Presence of Fucoxanthin pigment depicted as secondary peak in the Figure 9, which is a marker pigment along with chlorophyll supporting the presence of diatoms in the basin.

Figure 9. HPLC ancillary pigment concentration for the corresponding in-situ dates.

\section{CONCLUSIONS}

Our present seasonal observation of the phytoplankton bloom and its variability in the Godavari basin suggest that the strong possibility of occurrence of bloom in the winter season and its intensification in the summer season. This intensification of the phytoplankton blooms in the monsoonal estuaries (Godavari basin) may also due to the stability of the water column and enhancing light penetration. The bloom observed during early February and its intensification up to the May at the Godavari basin along the Kakinada coast, India was dominated by Skeletonema Costatum, a diatom species. The 8-day (weekly) products of Chlorophyll from OCM-2 during February to May indicated the changes in the area of blooming and their intensity during years from 2012 to 2014 in the northwestern Bay of Bengal. Subsequently, the monthly climatology chlorophyll data derived from MODIS also indicated high concentration in the Godavari basin with high intensified blooming in the summer season i.e., in the months of April and May. Even though the blooming observed regularly, the onset and termination period of blooming varied from year to year. The reason behind such changes and effect of the bloom could be due to the local environment and associated physical forcing. Different bloom regulators have different controlling mechanisms that lead to various potential bloom distribution patterns. Because of the optical complexity of this coastal study region the resulting bloom that occurred in the Godavari basin must have been regulated by a combination of various processes favoring the blooming conditions for the growth of phytoplankton. However, an intense time series observation is needed to understand the genesis of bloom in Godavari basin.

\section{ACKNOWLEDGEMENTS}

The authors would like to express their sincere thanks to the respective collaborators for participating in the cruise for collecting the data and project funding support and co-operation 
to carry out this work in a big way. The authors are also thankful to Ocean colour site for providing the climatology data and SeaDAS software package developed by NASA OBPG.

\section{REFERENCES}

Acharyya, T., Sarma, V. V. S. S., Sridevi, B., Venkataramana, V., Bharathi, M. D., Naidu, S., Kumar, B. S. K., Prasad, V. R., Bandopadhyay, D., Reddy, N. P. C., Kumar, M. D., 2012. Reduced river discharge intensifies phytoplankton bloom in Godavari estuary, India. Marine Chemistry, Vol. 132, pp. 15-22.

Choudhury, S. B., and Panigrahy, R. C., 1989. Occurrence of bloom of diatom Asterionella glacialis in nearshore waters of Gopalpur, Bay of Bengal. Indian Jounal of Marine Science, Vol. 18, pp. 204-206.

Darecki, M., Stramski, D., 2004. An evaluation of MODIS and SeaWiFS bio-optical algorithms in the Baltic Sea. Remote Sensing of Environment, Vol. 89, pp. 326-350.

Deshikachary, T.V., 1987. Atlas of diatoms. Fasicle (Marine diatoms of Indian Ocean region). Madras Science Foundation, Madras Plates, pp. 78-221.

Henson, S.A., Thomas, A.C., 2007. Interannual variability in timing of bloom initiation in the California current system. Journal of Geophysical Research-Oceans Vol. 112.

Kahru, M., Mitchell, B. G., 1999. Empirical chlorophyll algorithm and preliminary SeaWiFS validation for the California current. International Journal of Remote Sensing, Vol. 20, pp. 3423-3429.

Kim, H. J., Miller, A. J., McGowan, J., Carter, M., 2009. Coastal phytoplankton blooms in the Southern California Bight, Progress in Oceanography, Vol. 82, pp. 137-147.

Kim, H.J., Yoo, S.J., Oh, I.S., 2007. Relationship between phytoplankton bloom and wind stress in the sub-polar frontal area of the Japan/East Sea. Journal of Marine Systems, Vol. 67, pp. 205-216.

Mishra, S. and R. C. Panigraphy, Occurrence of diatom blooms in Bahuda estuary. East Coast of India. Ind. J. Mar. Sci., 24, 99-101, 1995.

Nageswara Rao, K., 2003. Coastal processes and forms of the Godavari delta.

O’Reilly, J. E., Maritorena, S, Mitchell, B. G., Siegel, D. A., Carder, K. L., Garver, S. A., Kahru, M., McClain, C. R., 1998. Ocean color chlorophyll algorithms for SeaWiFS. Journal of Geophysical Research, Vol. 103, pp. 24937 - 24953.

Panigraphy, R.C., and R. Gouda., 1990. Occurrence of bloom of the diatom Asterionella glacialis (Castracane) in the Rushikulya estuary, East Coast of India. Mahasagar, Vol. 23, pp. 179-182.

Preethi Latha, T., Nagamani, P. V., Rao, K. H., Dash, S. K., Choudhury, S. B., Sarma, V. V. S. S., Naveen Babu, M., Amrendra, P., Srinivasa Rao, B., Aziz Rehman, Prasad, T. D. v., 2014. Retrieval and Validation of Chlorophyll- $a$ concentrations in the Coastal Waters Off Yanam and Kakinada (Godavari) basin along East coast of India. Journal of Indian Society of Remote Sensing, Vol.42(1), pp. 129-138.
Richardson, K., and Jorgensen, B.B., 1996. Eutrophication: definition, history, an defects. American Geophysical Union, 119.

Sarma, V.V.S.S., et al., 2009. Influence of river discharge on plankton metabolic rates in the tropical monsoon driven Godavari estuary, India. Estuarine, Coastal and Shelf Science, Vol. 85(4), pp. 515-524.

Sarma, V.V.S.S., et al., 2010. Intra-annual variability in nutrients in the Godavari estuary, India. Continental Shelf Research, Vol. 30(19), pp. 2005-2014.

Siegel, D., Doney, S., Yoder, J., 2002. The North Atlantic spring phytoplankton bloom and Sverdrup's Critical Depth Hypothesis. Science, Vol. 296, pp. 730-733.

Shetye, S.R., Gouveia, A.D., Shenoi, S.S.C., Sundar, D., Michael, G.S., Almeida, A.A., Santanam, K., 1991.The coastal currents off western India during north east monsoon. Deep Sea Research Part A, Vol. 38, pp. 1517-1529.

Shetye, S.R., Gouveia, A.D., Shenoi, S.S.C., Sundar, D., Michael, G.S., Nampothiri, G., 1993. The Western boundary current of the seasonal subtropical gyre in the Bay of Bengal. Journal of Geophysical Research, Vol. 98, pp. 945-954.

Smayda, T. J., 1997. Harmful algal blooms: their ecophysiology and general relevance to phytoplankton blooms in the sea. Limnology \& Oceanography, Vol. 42, pp. 1137-1153.

Subba Rao., D. V., 1969. Asterionella Japonica bloom and discolouration Off Waltair, Bay of Bengal. Limnology \& Oceanography, Vol. 144, pp. 632-634.

http:// oceancolor.gsfc.nasa.gov.in/ 